Abstracta Iranicacta Iranica

Revue bibliographique pour le domaine irano-aryen

Volume 32-33 | 2013

Comptes rendus des publications de 2009-2010

\title{
B. J. Diebner. Foreign Rule Without Nasty Taste. The Persian Period Reflected in the TaNaK
}

\section{Astrid Nunn}

\section{(2) OpenEdition}

1 Journals

\section{Édition électronique}

URL : http://journals.openedition.org/abstractairanica/40244

DOI : 10.4000/abstractairanica.40244

ISSN : 1961-960X

Éditeur :

CNRS (UMR 7528 Mondes iraniens et indiens), Éditions de l'IFRI

\section{Édition imprimée}

Date de publication : 1 décembre 2013

ISSN : 0240-8910

\section{Référence électronique}

Astrid Nunn, «B. J. Diebner. Foreign Rule Without Nasty Taste. The Persian Period Reflected in the TaNaK ", Abstracta Iranica [En ligne], Volume 32-33 | 2013, document 54, mis en ligne le 01 juillet 2016,

consulté le 26 septembre 2020. URL : http://journals.openedition.org/abstractairanica/40244 ; DOI : https://doi.org/10.4000/abstractairanica.40244

Ce document a été généré automatiquement le 26 septembre 2020.

Tous droits réservés 


\title{
B. J. Diebner. Foreign Rule Without Nasty Taste. The Persian Period Reflected in the TaNaK
}

\author{
Astrid Nunn
}

\section{RÉFÉRENCE}

B. J. Diebner. « Foreign Rule Without Nasty Taste. The Persian Period Reflected in the TaNaK ». Trans. 38, 2009, p. 131-137.

1 Les mentions de l'époque perse dans le TaNaK (Torah, Nevi'im, Ketuvim) ne reflètent aucune réalité historique mais émanent d'une époque postérieure, même si l'époque perse y est présentée comme une période-type historique et comme idéal de la vie d'Israel « au milieu des nations ».

\section{AUTEURS}

\section{ASTRID NUNN}

Université de Munich 